\title{
A Study Of Curriculum Issues Related To Teaching Accounting Information Systems н
}

Sam Riner (Email: hsriner@saumag.edu), Southern Arkansas University

Terrye A. Stinson (Email: tastinson@saumag.edu), Southern Arkansas University

\begin{abstract}
This paper evaluates factors that educators believe contribute to an effective AIS course. Based on a survey of 100 faculty members, there is a lack of consensus about whether to include a computerized simulation in AIS, but respondents who do are less satisfied with the course than those who do not. Faculty members who are very satisfied with their AIS course consider coverage of internal controls and transaction cycles to be most important.
\end{abstract}

\section{Introduction}

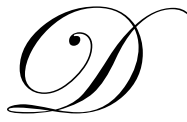

eveloping an understanding of accounting information systems (AIS) is an important objective for accounting educators. There is little agreement, however, about the relative importance of topics within college courses related to accounting information systems. A cursory examination of the tables of content in AIS textbooks demonstrates this lack of consensus. Some textbooks cover topics that are not included in other textbooks; furthermore, the order of presentation and the weight given topics vary considerably.

In light of these differences, this paper seeks to identify the factors that faculty members believe contribute to an effective AIS course. This information can then be used to improve accounting programs and curricula by focusing on the best practices developed by successful AIS educators.

\section{The State Of Accounting Information Systems Education}

One of the major challenges in accounting education involves the integration of technology throughout the curriculum. For those higher education institutions seeking to achieve or maintain accreditation, the integration of technology is essential. Appropriate integration is a particularly daunting challenge in the area of accounting information systems.

Rapid changes in technology have had a substantial impact on the accounting information systems used in businesses. Most small businesses now use computer-based accounting information systems. Many larger businesses have adopted sophisticated enterprise resource planning (ERP) management information systems that blur the distinctions between accounting and other aspects of business, such as production and marketing. Traditional standalone accounting information systems are increasingly regarded as inefficient and wasteful.

With ongoing changes in the way accounting is performed, there must also be changes in the way accounting is taught. As early as 1986, studies by the American Accounting Association (AAA) questioned the effectiveness of traditional teaching methods used by accounting educators, noting that accounting graduates often do not know how to communicate, reason logically, or solve problems in an efficient way. Over the last decade, many changes have occurred in accounting education, but these deficiencies continue to concern accounting educators. More recently, French and Coppage (2000, p. 69) concluded that academia continues to face the challenge of addressing the complexities of accounting systems in a rapidly changing business environment.

The American Institute of Certified Public Accountants' Core Competency Framework for Entry into the Accounting Profession identifies functional competencies, personal competencies, and broad business perspective 
competencies that are needed by accounting graduates (AICPA, 2003a). Each set culminates with the need for an ability to leverage technology to develop and enhance these competencies. Relating to functional competencies, the AICPA states, "Technology is pervasive in the accounting profession. Individuals entering the accounting profession must acquire the necessary skills to use technology tools effectively and efficiently. These technology tools can be used both to develop and apply other functional competencies (AICPA, 2003a)."

Concluding the discussion on the need for a broad business perspective, the AICPA states, "Technology alters how organizations operate. To provide the greatest value, today's accounting professional must understand and appreciate the effects of technology on the broader business environment (AICPA, 2003a)." Among the elements needed by accounting graduates, the AICPA lists the ability to access and use technology and the ability to explore new technologies and their application to business (AICPA, 2003a).

According to the AICPA, one purpose of the 150-hour requirement to sit for the Certified Public Accountant Examination is to provide accounting graduates with a high level of technical competence. The AICPA states, "Business methods have become increasingly complex. . Also, improvements in technology have had a major effect on information systems design, internal control procedures, and auditing methods (AICPA, 2003b).

The research and reports of both the American Accounting Association and the AICPA support the need for providing a strong technology component in accounting education. Each accounting course should address technology in an appropriate manner, and, for many programs, AIS can be an effective course for integrating the various facets of technology.

\section{Design of Study}

The data for this study were obtained through a survey distributed to 100 randomly selected AIS faculty members at schools of business that are either accredited by or are seeking accreditation from the AACSB. Surveys were addressed to AIS faculty members listed in the 2000-2001 Hasselback Directory of Accounting Faculty. Out of the 100 surveys distributed, 43 responses were received.

Survey questions were designed to elicit information about the AIS courses offered by the surveyed institutions and the faculty members' opinions concerning the content and structure of an accounting information course. More specifically, the survey questions were designed to determine:

- $\quad$ Does the faculty member's school offer a separate AIS course?

- What level is the AIS course?

- $\quad$ Is the AIS course a requirement for accounting majors?

- Is a computerized simulation included in the AIS course and, if so, what software is used?

- Is the faculty member satisfied with the AIS course?

- What percentage of class time is devoted to specific AIS topics?

- What is the instructor's opinion about the relative importance of specific AIS topics?

The data were analyzed by calculating frequencies and percentages of responses. The findings are presented in the next section of this study.

\section{Survey Results and Analysis of Data}

Results indicate that 95 percent of the surveyed institutions offer a separate AIS course, and 98 percent of these institutions require accounting majors to take the course. Based on the survey, 70 percent of responding schools offer AIS at the junior level, 20 percent offer AIS at the senior level, and 10 percent offer AIS at the sophomore level. Since most respondents require the AIS course and most offer it at the junior level, a logical conclusion follows that the AIS course may be considered foundational or a prerequisite for other accounting courses. 


\section{Computerized Simulations}

Considering that many accounting texts offer a simulation project as supplementary material, the survey asked respondents to indicate whether or not a computerized simulation was a required component of the AIS course. Survey results indicate a lack of consensus about the value of including such a project; 57 percent of respondents include a computerized simulation, and 43 percent do not.

For schools using a computerized simulation, the survey investigated the relative importance attached to the project by asking the percentage of class time allocated to the project and the percentage of the class grade allocated to the project. As indicated in table 1, both percentages varied widely.

Table 1: Comparison of Allocated Class Time versus Weight of Grade Assigned to Simulation

\begin{tabular}{|c|c|c|c|}
\hline $\begin{array}{l}\text { Percent of Class Time } \\
\text { Allocated to Simulation }\end{array}$ & Percent of Responses & $\begin{array}{c}\text { Percent of Grade Assigned } \\
\text { to Simulation }\end{array}$ & Percent of Responses \\
\hline $5-15 \%$ & $36 \%$ & $10-15 \%$ & $32 \%$ \\
\hline $20-30 \%$ & $36 \%$ & $20-25 \%$ & $40 \%$ \\
\hline $33-50 \%$ & $23 \%$ & $33-50 \%$ & $28 \%$ \\
\hline $100 \%$ & $5 \%$ & & \\
\hline
\end{tabular}

The percentage of class time allocated to the simulation ranged from a low of 5 percent to a high of 100 percent. On average, faculty reported allocating 27 percent of class time to the project. The percentage of the course grade allocated to the simulation ranged from 10 percent to 50 percent, with an average of 25 percent. These results indicate that there a lack of consensus about the amount of class time needed for a simulation, the weight the simulation should be given in assigning grades, and, on a more basic level, whether a simulation should be a requirement in the AIS course.

Respondents who used a simulation were asked to identify the type or brand of software used for the project. Over 60 percent used familiar software packages, such as Peachtree or QuickBooks; no respondent used any type of ERP software.

\section{Accounting Information Systems Topics}

The survey also asked respondents to indicate the percentage of class time devoted to the topics generally included in texts and to evaluate the relative importance of each topic. As shown in table 2, respondents allocate relatively more class time to the study of internal controls and the transaction cycles and allocate relatively less class time to the study of systems management, the systems life cycle, and EDP auditing. Most respondents (85\%) allocated 20 to 60 percent of class time to internal controls, and 86 percent devoted 20 to 60 percent of class time to transaction cycles.

Table 2: Percentage of Class Time Devoted to AIS Topics

\begin{tabular}{|l|c|c|c|c|c|}
\hline $\begin{array}{l}\text { Percent of } \\
\text { Class Time }\end{array}$ & $\begin{array}{c}\text { Systems } \\
\text { Management }\end{array}$ & Internal Control & $\begin{array}{c}\text { Systems Life } \\
\text { Cycle }\end{array}$ & $\begin{array}{c}\text { Transaction } \\
\text { Cycles }\end{array}$ & EDP Auditing \\
\hline $0-20$ & $69 \%$ & $15 \%$ & $85 \%$ & $10 \%$ & $87 \%$ \\
\hline $20-40$ & $29 \%$ & $70 \%$ & $15 \%$ & $78 \%$ & $13 \%$ \\
\hline $41-60$ & $2 \%$ & $15 \%$ & & $8 \%$ & \\
\hline $61-80$ & & & & $4 \%$ & \\
\hline
\end{tabular}


Similarly, most respondents consider coverage of internal controls and transaction cycles to be key elements in the AIS curriculum. As shown in table 3, 88 percent of respondents consider coverage of internal controls to be very important, and 72 percent consider transaction cycles very important.

Table 3: Relative Importance of AIS Topics

\begin{tabular}{|l|c|c|c|c|c|}
\hline & $\begin{array}{c}\text { Systems } \\
\text { Management }\end{array}$ & $\begin{array}{c}\text { Internal } \\
\text { Control }\end{array}$ & $\begin{array}{c}\text { Systems Life } \\
\text { Cycle }\end{array}$ & $\begin{array}{c}\text { Transaction } \\
\text { Cycles }\end{array}$ & EDP Auditing \\
\hline Very Important & $23 \%$ & $88 \%$ & $15 \%$ & $72 \%$ & $26 \%$ \\
\hline Somewhat Important & $47 \%$ & $12 \%$ & $55 \%$ & $28 \%$ & $36 \%$ \\
\hline Neutral & $29 \%$ & & $25 \%$ & & $36 \%$ \\
\hline Not Important & $1 \%$ & & $5 \%$ & & $2 \%$ \\
\hline
\end{tabular}

Comparing time versus importance, however, indicates some unexpected results. The majority $(69 \%$ or more) of respondents allocate less than 20 percent of class time to the other listed topics (systems management, the systems life cycle, and EDP auditing), but respondents still consider these topics at least somewhat important.

\section{Level Of Satisfaction}

Based on the assumption that faculty who are most satisfied with the AIS curriculum have developed an effective curriculum for the class, the survey used level of satisfaction as a proxy for effectiveness. Results indicate that 36.5 percent of respondents are very satisfied with their AIS course, while 58.5 percent are somewhat satisfied, and 5 percent are dissatisfied. To identify the best practices used by very satisfied faculty members, their responses related to computerized simulation projects and effective course content were reevaluated.

Survey results indicate that respondents who are very satisfied with the AIS course are less likely to require a computerized simulation than others. Only 40 percent of the respondents who are very satisfied use such a project, whereas 71 percent of those who are somewhat satisfied use a computerized simulation.

With two exceptions, the percentage of class time allocated to each topic is essentially the same for all respondents, regardless of their level of satisfaction. First, respondents who are very satisfied spend more time on transaction cycles than do others; second, they allocate less time to systems management than do others. Table 4 shows the allocation of class time reported by respondents who were either very satisfied or somewhat satisfied.

Table 4: Level of Satisfaction and Class Time Allocated to Subject Areas

\begin{tabular}{|c|c|c|c|c|c|c|c|c|c|c|}
\hline \multirow{2}{*}{$\begin{array}{l}\text { Percentage } \\
\text { of Class } \\
\text { Time }\end{array}$} & \multicolumn{2}{|c|}{$\begin{array}{c}\text { Systems } \\
\text { Management }\end{array}$} & \multicolumn{2}{|c|}{$\begin{array}{c}\text { Internal } \\
\text { Control } \\
\end{array}$} & \multicolumn{2}{|c|}{$\begin{array}{l}\text { Systems Life } \\
\text { Cycle }\end{array}$} & \multicolumn{2}{|c|}{$\begin{array}{c}\begin{array}{c}\text { Transaction } \\
\text { Cycles }\end{array} \\
\end{array}$} & \multicolumn{2}{|c|}{$\begin{array}{c}\text { EDP } \\
\text { Auditing }\end{array}$} \\
\hline & $\begin{array}{c}\text { Very } \\
\text { Satisfied }\end{array}$ & $\begin{array}{c}\text { Some- } \\
\text { what } \\
\text { Satisfied }\end{array}$ & $\begin{array}{c}\text { Very } \\
\text { Satisfied }\end{array}$ & $\begin{array}{c}\text { Some- } \\
\text { what } \\
\text { Satisfied }\end{array}$ & $\begin{array}{c}\text { Very } \\
\text { Satisfied }\end{array}$ & $\begin{array}{c}\text { Some- } \\
\text { what } \\
\text { Satisfied }\end{array}$ & $\begin{array}{c}\text { Very } \\
\text { Satisfied }\end{array}$ & $\begin{array}{c}\text { Some- } \\
\text { what } \\
\text { Satisfied }\end{array}$ & $\begin{array}{c}\text { Very } \\
\text { Satisfied }\end{array}$ & $\begin{array}{c}\text { Some- } \\
\text { what } \\
\text { Satisfied }\end{array}$ \\
\hline 0 to 20 & $86 \%$ & $59 \%$ & $13 \%$ & $13 \%$ & $86 \%$ & $83 \%$ & $14 \%$ & $9 \%$ & $86 \%$ & $86 \%$ \\
\hline 20 to 40 & $14 \%$ & $37 \%$ & $74 \%$ & $74 \%$ & $14 \%$ & $17 \%$ & $66 \%$ & $83 \%$ & $14 \%$ & $14 \%$ \\
\hline 41 to 60 & & $4 \%$ & $13 \%$ & $13 \%$ & & & $20 \%$ & $0 \%$ & & \\
\hline 61 to 80 & & & & & & & & $9 \%$ & & \\
\hline
\end{tabular}

Like all respondents, those who are very satisfied consider coverage of internal controls and the transaction cycles to be very important. However, comparing the responses of those who are very satisfied with those who are somewhat satisfied provides three observable differences. As shown in table 5, those who are very satisfied assign a higher level of importance to covering (1) transaction cycles, (2) the systems life cycle, and (3) EDP auditing than do those who are somewhat satisfied. 
Table 5: Level of Satisfaction and Importance of Subject Areas

\begin{tabular}{|c|c|c|c|c|c|c|c|c|c|c|}
\hline \multirow{2}{*}{$\begin{array}{l}\text { Importance } \\
\text { of Subject } \\
\text { Area }\end{array}$} & \multicolumn{2}{|c|}{$\begin{array}{c}\text { Systems } \\
\text { Management }\end{array}$} & \multicolumn{2}{|c|}{$\begin{array}{c}\text { Internal } \\
\text { Control } \\
\end{array}$} & \multicolumn{2}{|c|}{$\begin{array}{c}\begin{array}{c}\text { Systems Life } \\
\text { Cycle }\end{array} \\
\end{array}$} & \multicolumn{2}{|c|}{$\begin{array}{c}\begin{array}{c}\text { Transaction } \\
\text { Cycles }\end{array} \\
\end{array}$} & \multicolumn{2}{|c|}{$\begin{array}{c}\text { EDP } \\
\text { Auditing }\end{array}$} \\
\hline & $\begin{array}{c}\text { Very } \\
\text { Satisfied }\end{array}$ & $\begin{array}{c}\text { Some- } \\
\text { what } \\
\text { Satisfied }\end{array}$ & $\begin{array}{c}\text { Very } \\
\text { Satisfied }\end{array}$ & $\begin{array}{c}\text { Some- } \\
\text { what } \\
\text { Satisfied }\end{array}$ & $\begin{array}{c}\text { Very } \\
\text { Satisfied }\end{array}$ & $\begin{array}{c}\text { Some- } \\
\text { what } \\
\text { Satisfied }\end{array}$ & $\begin{array}{c}\text { Very } \\
\text { Satisfied }\end{array}$ & $\begin{array}{c}\text { Some- } \\
\text { what } \\
\text { Satisfied }\end{array}$ & $\begin{array}{c}\text { Very } \\
\text { Satisfied }\end{array}$ & $\begin{array}{c}\text { Some- } \\
\text { what } \\
\text { Satisfied }\end{array}$ \\
\hline $\begin{array}{l}\text { Very } \\
\text { Important }\end{array}$ & $27 \%$ & $23 \%$ & $87 \%$ & $87 \%$ & $20 \%$ & $13 \%$ & $86 \%$ & $61 \%$ & $40 \%$ & $19 \%$ \\
\hline $\begin{array}{l}\text { Somewhat } \\
\text { Important }\end{array}$ & $47 \%$ & $46 \%$ & $13 \%$ & $13 \%$ & $67 \%$ & $53 \%$ & $14 \%$ & $39 \%$ & $27 \%$ & $41 \%$ \\
\hline Neutral & $26 \%$ & $28 \%$ & & & $13 \%$ & $26 \%$ & & & $33 \%$ & $37 \%$ \\
\hline $\begin{array}{l}\text { Not } \\
\text { Important }\end{array}$ & & $3 \%$ & & & & $8 \%$ & & & & $3 \%$ \\
\hline
\end{tabular}

\section{Conclusions}

Based on the survey results, most schools offer the accounting information systems class at the junior level and require that accounting majors take the class. Therefore, AIS may be considered a foundational or prerequisite for other accounting courses, such as auditing.

Slightly more than half of respondents include a computerized simulation in AIS, but respondents who are very satisfied with the course are less likely to require one than others are. This decision may relate to problems and uncertainty associated with software products and computer labs. Conceptually, a computerized simulation may contribute to an effective curriculum, but software and hardware problems may create frustrations for both faculty and students.

Those who are very satisfied with the AIS course have somewhat different perceptions of the importance of certain AIS topics. Overall, internal controls and transaction cycles are considered key elements of the AIS course, and more class time is generally allocated to these topics. Those who are very satisfied with the AIS course, however, assign a relatively higher level of importance to covering transaction cycles, the systems life cycle, and EDP auditing than do others. Furthermore, those who are very satisfied tend to allocate more time to covering transaction cycles than do others.

Accounting educators face a continuing challenge to prepare accounting graduates for a career in a profession where technology is pervasive. The results of this study contribute information that may assist educators in identifying best practices for developing the curriculum in accounting information systems. By studying the methods used by successful peers, accounting educators can gain insight to improve the curriculum and enhance the academic preparation for students.

\section{Suggestions For Future Research}

Further research is needed to determine benefits and problems related to integrating technology with simulation projects. Further research is needed to determine if an AIS faculty member who is very satisfied with the curriculum uses different pedagogical approaches for presenting material in the classroom. Additional research may determine if differences in professional and academic experience influence a faculty member's perceptions about the AIS course. Those educators with greater industry experience or more recent degrees may approach the AIS course somewhat differently than those with different backgrounds. 


\section{References}

1. American Institutes of Certified Public Accountants (2003a), AICPA Core Competency Framework for Entry into the Accounting Profession (The Framework), available at www.aicpa.org/edu/corecomp.htm.

2. American Institutes of Certified Public Accountants (2003b), AICPA 150-Hour Requirement, available at www.aicpa.org/nolimits/become/150hr/index.htm.

3. French, G. Richard and Richard E. Coppage, "Educational Issues Challenging the Future of the Accounting Profession," Ohio CPA Journal, July-September 2000, p. 69-73.

Notes 